\title{
Canonical transient receptor potential 4 and its small molecule modulators
}

\author{
FU Jie ${ }^{1,2}$, GAO ZhaoBing ${ }^{2}$, SHEN Bing ${ }^{1} \&$ ZHU Michael X. ${ }^{2,3 *}$ \\ ${ }^{1}$ Department of Physiology, Anhui Medical University, Hefei 230032, China; \\ ${ }^{2}$ International Scientist Workstation of Neuropharmacology, Shanghai Institute of Materia Medica, Chinese Academy of Sciences, \\ Shanghai 201203, China; \\ ${ }^{3}$ Department of Integrative Biology and Pharmacology, the University of Texas Health Science Center at Houston, Houston, Texas 77030 , \\ USA
}

Received August 16, 2014; accepted September 6, 2014; published online December 4, 2014

\begin{abstract}
Canonical transient receptor potential 4 (TRPC4) forms non-selective cation channels that contribute to phospholipase $\mathrm{C}$-dependent $\mathrm{Ca}^{2+}$ entry into cells following stimulation of $\mathrm{G}$ protein coupled receptors and receptor tyrosine kinases. Moreover, the channels are regulated by pertussis toxin-sensitive $\mathrm{G}_{\mathrm{i} / \mathrm{o}}$ proteins, lipids, and various other signaling mechanisms. TRPC4-containing channels participate in the regulation of a variety of physiological functions, including excitability of both gastrointestinal smooth muscles and brain neurons. This review is to present recent advances in the understanding of physiology and development of small molecular modulators of TRPC4 channels.
\end{abstract}

TRPC4 channel, non-selective cation channel, G protein coupled receptors, small molecular modulators, G proteins, excitation, contraction, $\mathrm{Ca}^{2+}$ signaling

Citation: $\quad F u$ J, Gao ZB, Shen B, Zhu MX. Canonical transient receptor potential 4 and its small molecule modulators. Sci China Life Sci, 2015, 58: 39-47, doi: $10.1007 / \mathrm{s} 11427-014-4772-5$

The transient receptor potential (TRP) protein superfamily consists of a diverse group of non-selective cation channels, which are implicated in multiple signal transduction pathways, with particular importance in sensory physiological responses to temperature, light, smell, taste, as well as mechanical and painful chemical stimuli [1,2]. The canonical subfamily of TRP (TRPC) channels are closely related to the prototypical Drosophila TRP protein, with 30\%-40\% amino acid sequence identity [3]. Seven mammalian TRPC proteins (TRPC1-7) have been identified and based on amino acid sequence similarity, they are further divided into three groups: TRPC1/C4/C5, TRPC3/C6/C7 and TRPC2 [4]. Channels formed by TRPC proteins are composed of four subunits, which are either identical or different. It is well

*Corresponding author (email: Michael.x.zhu@uth.tmc.edu) accepted that TRPC members within the same group can form heterotetrameric channels [5], but evidence also exists for heterotetramers formed between members from different groups. For example, TRPC3 and TRPC4 can associate to form a redox-sensitive cation channel in endothelial cells [6]. Notably, TRPC1 has been shown to partner not only with members of the TRPC subfamily, e.g., TRPC3, TRPC4, and TRPC5, but also with other TRP proteins, e.g., TRPP2, TRPV4, and TRPV6 [7-10].

The first full-length TRPC4 cDNA sequence was reported for a clone isolated from bovine adrenal gland [11]. Since then, several TRPC4 orthologues, including splice variants, had been isolated from a number of other species such as rat, mouse and human, and some of them had been functionally examined [11,12]. In rat, mouse and human, the most abundant transcripts of TRPC4 appear to be 
TRPC $4 \alpha$ and TRPC4 $\beta$. The two isoforms vary only at the C-terminus, in which the TRPC $4 \beta$ variant lacks a region containing 84 amino acids as compared to TRPC $4 \alpha[13,14]$ (Figure 1). While TRPC4 is predominately expressed in the brain, it is also found in diverse tissues including endothelia, adrenal gland, smooth muscles of the gastrointestinal track, placenta and testis [19].

\section{Structure and biological relevance of TRPC4}

Like other TRP channels, a single TRPC4 subunit has six transmembrane segments (S1-S6) with a putative pore-forming region (P-loop) between the fifth (S5) and sixth (S6) segments and intracellularly localized $\mathrm{N}$ - and C-termini [2]. Within the cytoplasmic N-terminus of TRPC4, four ankyrin-like repeats, a calmodulin (CaM) binding site, a coiled-coil domain and a caveolin-binding site have been identified [2,4]. In the cytoplasmic C-terminus, there are a TRP box (a stretch of relatively conserved six residues found in all members of TRPCs, TRPMs, and TRPVs [1] and in the case of TRPCs is EWKFAR), a second coiled-coil domain, a conserved protein 4.1-binding domain, and a shared binding site for CaM and inositol 1,4,5-trisphosphate receptors $\left(\mathrm{IP}_{3} \mathrm{Rs}\right)$ [15,16,20]. Interestingly, the $\mathrm{CaM}$ and $\mathrm{IP}_{3} \mathrm{R}$ binding (CIRB) site also binds to SESTD1, a protein that contains a SEC14-like lipid binding domain and two spectrin domains and binds phosphoinositides in a $\mathrm{Ca}^{2+}$-dependent fashion [21]. It also appears to be critical for the stimulatory effect of $\mathrm{G \alpha}_{\mathrm{i} / \mathrm{o}}$ proteins on TRPC4 channels [22]. These suggest that the CIRB site may be the converging point of TRPC4 channel gating by multiple factors, such as $\mathrm{Ca}^{2+}-\mathrm{CaM}, \mathrm{IP}_{3} \mathrm{Rs}, \mathrm{G}_{\mathrm{i} / \mathrm{o}}$ proteins, phosphoinositides, and cytoskeleton (Figure 1). Additionally, the region immediately downstream of the TRPC4 CIRB site also binds spectrins [23].

The last three C-terminal amino acids (TRL) of TRPC4 comprise a PDZ-interacting domain. PDZ domains were identified as 80-100 amino acid repeated sequences in the synapse-associated protein PSD-95, the human homolog of the Drosophila Dlg protein (hdlg) and the epithelial tight-junction protein zona occludens-1 (ZO-1) [24]. Within the TRPC subfamily, this TRL motif is specific for TRPC4 and TRPC5. The PDZ-binding motif TRL interacts with regulatory factor of the $\mathrm{Na}^{+} / \mathrm{H}^{+}$exchanger (NHERF), also known as ezrin/radixin/moesin-50 (ERM50). The PDZ motifs of NHERF/EBP50 bind to the TRPC4/C5 channels and phospholipase $\mathrm{C} \beta$ (PLC $\beta$ ), and link the lipase and the channels to the actin cytoskeleton [25], via the actin-binding membrane-cytoskeletal adaptors, ezrin, radixin, and moesin (ERM) [26]. As a result, the PDZ-interacting domain regulates the localization and surface expression of TRPC4 [26].

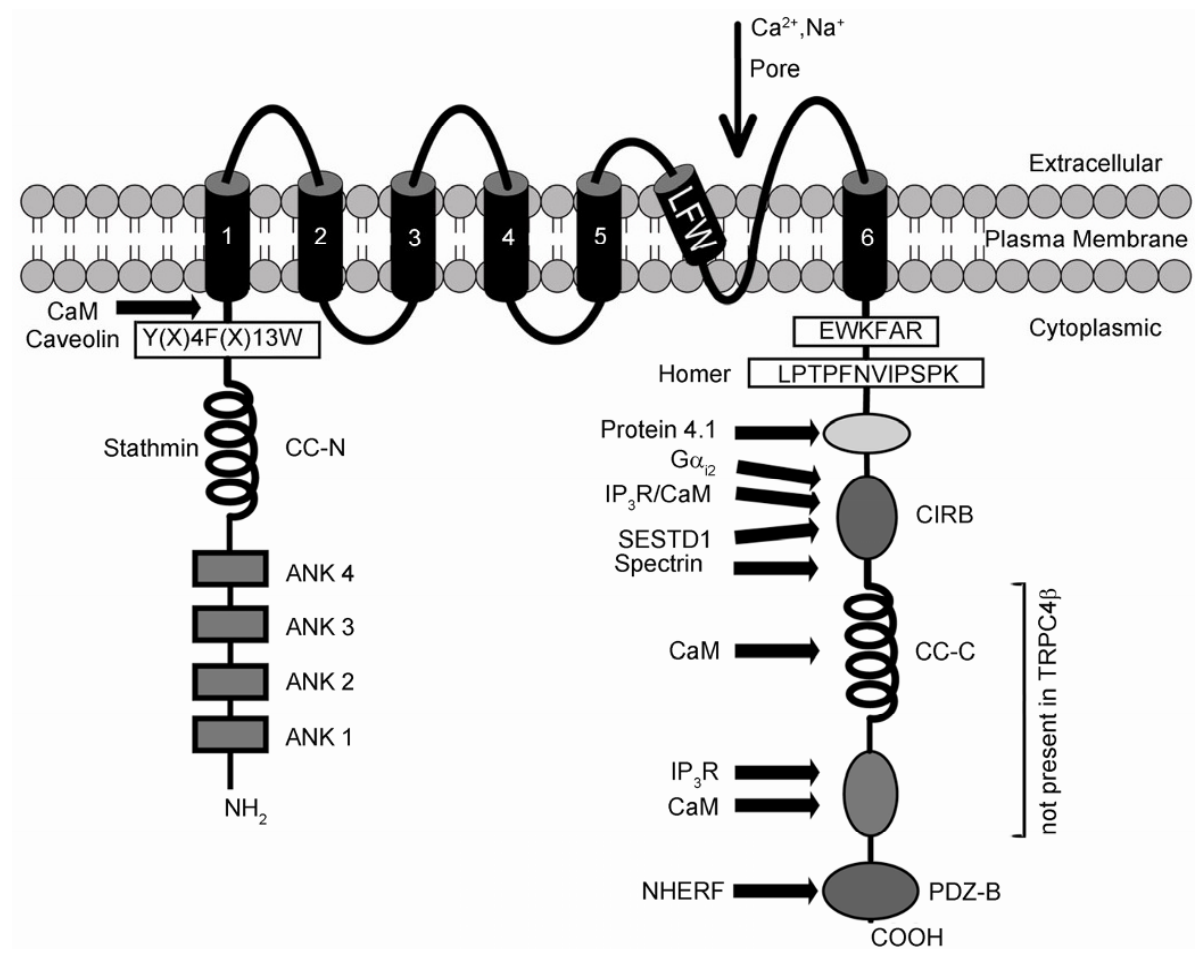

Figure 1 Structural features of TRPC4 $\alpha$, which contains an extra region with 84 amino acids as compared to TRPC4 $\beta$. Within this region, two calmoudlin $(\mathrm{CaM})$ binding motifs and one $\mathrm{IP}_{3}$ receptor binding domain had been experimentally identified [15,16]. Homer had been suggested to bind to the proline-rich region of the related TRPC1 [17]. Stathmin was shown to bind to the N-terminal coiled-coil domains (CC-N) of TRPC4 and TRPC5 [18]. Other domains and interacting proteins are described in the text. ANK 1-4, ankyrin-like repeats $1-4$; CC-C, C-terminal coiled-coil domains, CIRB, calmodulin/IP ${ }_{3}$ receptor binding region; PDZ-B, PDZ binding domain; LFW, amino acid motif conserved in the hydrophobic putative pore region; EWKFAR, sequence of the TRP box. Adapted from [4] with modifications. 
TRPC4 shares an overall $65 \%$ sequence identity with TRPC5. However, the similarity is not evenly distributed throughout the full-length sequences between the two proteins. TRPC4 and TRPC5 are quite similar at the N-termini, transmembrane domains, and the beginning of the C-termini encompassing the TRP motifs (83\% identity for aa1-665 of TRPC4 and aa1-669 of TRPC5), as well as the CIRB sites and the spectrin-binding sites (77\% identity for aa695-754 of TRPC4 and aa702-761 of TRPC5). However, the rest of the C-termini, encompassing $>200$ residues (aa755-974 of TRPC4 $\alpha$ and aa762-975 of TRPC5), bear virtually no homology, except for the final convergence of the last five residues, VTTRL, in which the last three residues are critical for binding to NHERF, as explained above. Therefore, although it has often been thought that TRPC4 and TRPC5 are regulated similarly, differences should exist between the two channels.

In terms of physiological functions, channels formed by TRPC4 are often distinct from those composed of TRPC5. TRPC4 has been suggested to be a key determinant of endothelial $\mathrm{Ca}^{2+}$ signaling and of endothelial cell functions, such as nitric oxide release and barrier stability [27,28]. Vascular endothelial cells from $\mathrm{TRPC}^{-/-}$mice lacked store-operated $\mathrm{Ca}^{2+}$ currents [27]. Therefore, TRPC4 appeared to be an indispensable component of store-operated channels in vascular endothelial cells and these channels directly provide a $\mathrm{Ca}^{2+}$ entry pathway essential for the regulation of blood vessel tone [27]. Similarly, lung vascular endothelial cells isolated from TRPC4 ${ }^{-/}$mice showed reduced $\mathrm{Ca}^{2+}$ responses to thrombin and PAR-1 peptide [28]. These were associated with a lack of actin stress fiber formation, deficiencies in the endothelial cell retraction response and an increase in vascular permeability [28]. In neuroendocrine cells, activation of transiently expressed TRPC4 via stimulation of co-expressed histamine receptor type $1\left(\mathrm{H}_{1} \mathrm{R}\right)$ provided enough $\mathrm{Ca}^{2+}$ influx to trigger a robust secretory response comparable to that activated by a train of depolarizing pulses [29]. TRPC4 was also shown to be critically involved in the $\mathrm{Ca}^{2+}$ entry pathway needed for serotonin-induced dendritic release of $\gamma$-aminobutyric acid (GABA) from interneurons onto thalamic relay neurons [30]. In addition, TRPC1-TRPC4 heteromeric channels are thought to mediate the plateau potential and epileptiform discharge evoked by agonists of group 1 metabotropic glutamate receptors (mGluRs) in lateral septal and CA1 hippocampal neurons [31-33]. These channels are also involved in neurodegeneration induced by severe epileptic seizures in these brain regions [32]. Likewise, the TRPC1-TRPC4 channels are important for neurotransmission at dendritic-dendritic synapses between mitral/tufted cells and granule cells in the olfactory bulb, which manifests as long lasting depolarization and sustained $\mathrm{Ca}^{2+}$ influx in the granule cells [34]. In the gastrointestinal system, comparison of the properties between native currents in interstitial cells of
Cajal (ICC) and ionic currents of heterologously expressed TRPC4 in HEK293 cells revealed a very similar current-voltage $(I-V)$ relationship, indicating that TRPC4 is a strong candidate of the pacemaker channel in ICC $[35,36]$. Similarly, in intestinal smooth muscle cells, TRPC4 forms a 55 -pS cation channel and underlies at least $80 \%$ of the muscarinic agonist-elicited cation currents $\left(\mathrm{mI} I_{\mathrm{CAT}}\right)$ [37]. In TRPC4-deficient ileal myocytes the carbachol-induced membrane depolarization was diminished greatly and the atropine-sensitive contraction elicited by acetylcholine released from excitatory motor neurons was markedly reduced as well [37]. TRPC4 and to a lesser extent, TRPC6, channels couple muscarinic receptors to depolarization of intestinal smooth muscle cells and activation of voltage-gated $\mathrm{Ca}^{2+}$ channels to mediate $\mathrm{Ca}^{2+}$ influx and contraction, and thereby accelerate motility of small intestine in vivo [37]. Additional functions of TRPC4 also include formation of normal-sized myotubes during postnatal human myogenesis [38], keratinocyte differentiation [39], neurite extension of human postmitotic neurons [40]. In single-nucleotide polymorphism (SNP) studies, variants of TRPC4 have been associated with photoparoxysmal response/idiopathic generalized epilepsies [41]; a gain-offunction variant (I957V) of TRPC4 was found to be associated with a lower incidence of myocardial infarction in diabetic patients [42].

For functions that appear to overlap with TRPC5, both TRPC1-TRPC4 and TRPC5 channels may be involved in seizure-induced neuronal death in mouse hippocampus [32]. In certain populations of proopiomelanocortin neurons, channels composed of TRPC1, TRPC4, and/or TRPC5 may mediate the effect of leptin acting at the long-form leptin receptor [43]. In neurons of lateral amygdala, TRPC4 seems to mediate the postsynaptic responses triggered by the activation of either group 1 mGluRs or cholecystokinin 2 receptors. This effect is involved in innate fear responses just like that mediated by TRPC5 $[44,45]$.

\section{Activation mechanism and electrophysiolog- ical properties}

It is widely agreed that the opening of TRPC4 channels requires activation of receptors coupled to the $G_{q / 11}$ family of $\mathrm{G}$ proteins, which communicate with PLC $\beta$, or receptor tyrosine kinases, which stimulate PLC $\gamma[13,46]$. The activation of PLC leads to hydrolysis of phosphatidylinositol 4,5-bisphosphate $\left(\mathrm{PI}(4,5) \mathrm{P}_{2}\right)$, producing diacylglycerols (DAG) and inositol 1,4,5-trisphosphate $\left(\mathrm{IP}_{3}\right)$. Intracellular dialysis of $\mathrm{PI}(4,5) \mathrm{P}_{2}$ was shown to inhibit TRPC $4 \alpha$ but not TRPC $4 \beta$ [47]. However, TRPC4 $\beta$ activation seems to require $\mathrm{PI}(4,5) \mathrm{P}_{2}$, as not only manipulations that reduced $\mathrm{PI}(4,5) \mathrm{P}_{2}$ availability inhibited the channel activation, but also supplementation of exogenous $\mathrm{PI}(4,5) \mathrm{P}_{2}$ to the cytoplasmic side suppressed channel desensitization $[22,48]$. It 
would be interesting to know if the $\mathrm{PI}(4,5) \mathrm{P}_{2}$ requirement depends on the lipid itself, as in the case of several members of the TRPM subfamily [49-52] or one of its hydrolysis products, as suggested for the TRPC $3 / \mathrm{C} 6 / \mathrm{C} 7$ subgroup [53].

However, different from the TRPC $3 / \mathrm{C} 6 / \mathrm{C} 7$ subgroup, TRPC4 (and TRPC5) is not activated by DAGs. Uniquely, it becomes activated following the stimulation of receptors that couple to pertussis toxin (PTX) sensitive $\mathrm{G}_{\mathrm{i} / \mathrm{o}}$ proteins [22]. The muscarinic cation current $\left(\mathrm{mI}_{\mathrm{CAT}}\right)$ in intestinal smooth muscle cells represents the best characterized native channel activity of TRPC4 [37]. It has long been recognized that both $\mathrm{G}_{\mathrm{i} / 0}$-coupled $\mathrm{M} 2$ and $\mathrm{G}_{\mathrm{q} / 11}$-coupled M3 muscarinic receptors are involved in the activation of $\mathrm{mI}_{\mathrm{CAT}}$ [54]. Not surprisingly, treatment with PTX inhibited both native $\mathrm{mI}$ САT and heterologously expressed TRPC4 channels no matter the activation was induced by a muscarinic agonist or GTP $\gamma \mathrm{S}$ [47,55]. Also interesting is that the effect of $\mathrm{G}_{\mathrm{i} / \mathrm{o}}$ appears to be mediated by the $\mathrm{G} \alpha$ but not $\mathrm{G} \beta \gamma$ subunits and the study using GTPase-deficient $G \alpha_{\mathrm{i} / \mathrm{o}}$ subunits revealed for a preference of $\mathrm{G} \alpha_{\mathrm{i} 2}$ for TRPC4 and $\mathrm{G} \alpha_{\mathrm{i} 3}$ for TRPC5 [22]. Intriguingly, the same study also found that the critical region on TRPC4 for interacting and functional coupling by $\mathrm{G} \alpha_{i}$ proteins overlaps with the C-terminal CIRB site [22], implying a pivotal role of this motif in overall gating of TRPC channels. Furthermore, the CIRB motif of TRPC4 and TRPC5 had previously been shown to bind to SESTD1, through which the channel could be regulated by phosphoinositides, $\mathrm{Ca}^{2+}$ and cytoskeleton [21]. Therefore, sorting out the interplay among $\mathrm{Ca}^{2+}, \mathrm{CaM}, \mathrm{IP}_{3} \mathrm{Rs}, \mathrm{G \alpha}_{\mathrm{i}}$ 's, SESTD1, phosphoinositides, and cytoskeleton at the CIRB motif should be of great significance in elucidating molecular mechanism(s) of TRPC4 channel activation.

In addition to the mechanisms discussed above, TRPC4 channels had also been shown to respond to mercury compounds [56] and nitric oxide (NO) [57]. Early studies had implied a role of TRPC4-containing channels in storeoperated $\mathrm{Ca}^{2+}$ entry $[27,28,58,59]$; however, it is unclear whether this represented a direct gating by STIM1, which senses the store depletion signal $[60,61]$, or an indirect effect of intracellular $\mathrm{Ca}^{2+}$ rise resulting from either $\mathrm{Ca}^{2+}$ release from internal stores or $\mathrm{Ca}^{2+}$ influx mediated by "real" store-operated channels formed by Orai proteins [62]. The latter argument is possible because activation of TRPC4 channels is dependent on intracellular $\mathrm{Ca}^{2+}$ rise [13].

In whole-cell recordings, the agonist-induced currents of TRPC4 have a nonlinear $I-V$ relationship, typically with an outward rectification at positive potentials and a $\mathrm{U}$ - or $\mathrm{V}$-shaped $I-V$ relation at negative potentials $[13,47]$. The currents reverse at close to $0 \mathrm{mV}$, but there is a flat region between 0 and $+40 \mathrm{mV}$ (Figure 2), which can be eliminated by the removal of $\mathrm{Mg}^{2+}$ from both sides of the membrane $[13,14]$. In excised inside-out patches, TRPC4 has a reported single channel conductance of $42 \mathrm{pS}$ [13].

\section{Pharmacology}

\subsection{TRPC4 activators}

To date, no specific activator of TRPC4 has been reported. In most studies, TRPC4-containing channels, either native or heterologously expressed, are commonly activated by the stimulation of G-protein coupled receptors or receptor tyrosine kinases $[13,37,47,54]$. Sometimes, intracellular dialysis of GTP $\gamma \mathrm{S}$ or NaF was used to activate TRPC4 through direct stimulation of $\mathrm{G}$ proteins $[13,47,63]$. In inside-out membrane patches, TRPC4 currents were strongly increased by application to the cytoplasmic side of calmidazolium, a $\mathrm{CaM}$ antagonist, or a peptide that represented the TRPCbinding domain of the type $3 \mathrm{IP}_{3} \mathrm{R}$ [15].

Lanthanides are the most commonly used inhibitors of nonselective cation channels and $\mathrm{Ca}^{2+}$ channels and they do inhibit TRPC3, C6, and C7. However, in the case of TRPC4 and TRPC5, high micromolar concentrations of lanthanides potentiate their currents [64]. Neutralization of negatively charged amino acid residues, E543, E595 and E598, situated close to the segments S5 and S6 of TRPC5, resulted in a loss of potentiation by lanthanides [64]. These residues are conserved in TRPC4. Because other TRPC isoforms and native cation channels are inhibited by lanthanides, the potentiation of TRPC4 and TRPC5 by micromolar $\mathrm{La}^{3+} / \mathrm{Gd}^{3+}$ represents a unique property that is useful for establishing the contribution of these TRPC isoforms in native tissues $[43,65]$.

\subsection{TRPC4 inhibitors}

ML204 has been reported as a novel, potent, and selective TRPC4 channel inhibitor [66]. ML204 inhibited intracellular $\mathrm{Ca}^{2+}$ rise mediated by TRPC4 $\beta$ with an $\mathrm{IC}_{50}$ value of approximately $1 \mu \mathrm{mol} \mathrm{L} \mathrm{L}^{-1}$ and it exhibited a 19-fold selectivity for TRPC4 over TRPC6 [66]. Results from whole-cell patch clamp recordings suggested that ML204 most likely exerted a direct inhibitory effect on the TRPC4 channel rather than acted through an interference with the signal transduction pathways [66]. Selectivity studies showed that ML204 had no appreciable inhibition on TRPV1, TRPV3, TRPA1, and TRPM8, or native voltage-gated sodium, potassium, and calcium channels in mouse dorsal root ganglion neurons. Therefore, ML204 appears to be an excellent chemical tool for modulating TRPC4 or TRPC5 channels [66]. Recently, ML204 has been successfully used to identify the functions of native TRPC4 and/or TRPC5 channels in visceral pain [67], kidney filtration barrier deregulation [68], and neuronal excitability regulation [69].

Flufenamic acid (FFA), mefenamic acid (MFA), niflumic acid (NFA) and diclofenac sodium (DFS) have been shown to inhibit TRPC4 and TRPC5 channels in a concentration-dependent manner [70]. However, these drugs are known to have other targets [71,72] and they are not potent 

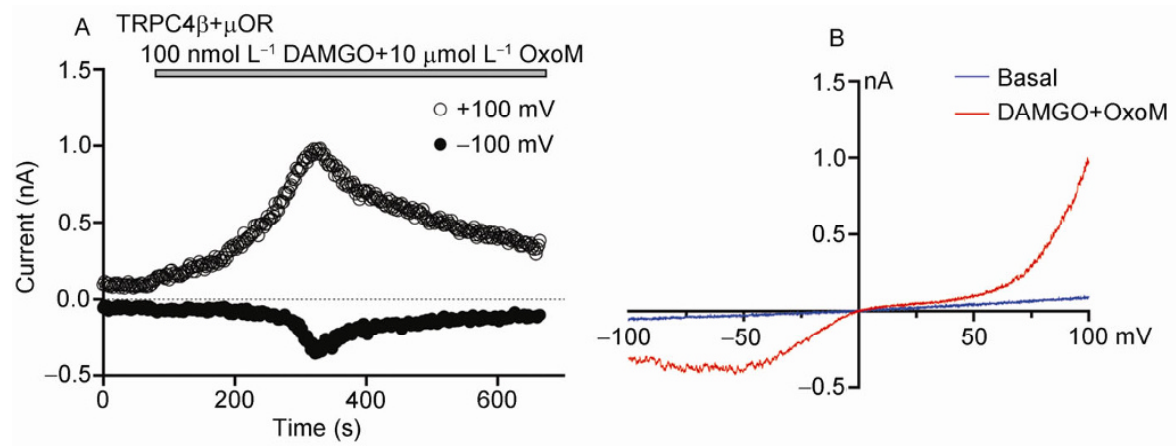

Figure 2 Agonist-activated currents in a HEK293 cell that co-expressed mouse TRPC4 $\beta$ and $\mu$-opioid receptor ( $\mu \mathrm{OR}$ ). A, For whole-cell experiments, the standard extracellular solution contained (in mmol L-1): $140 \mathrm{NaCl}, 5 \mathrm{KCl}, 2 \mathrm{CaCl}_{2}, 1 \mathrm{MgCl}_{2}, 10$ glucose, $10 \mathrm{HEPES}$, pH 7.4 adjusted with NaOH. The intracellular solution consisted of (in mmol L ${ }^{-1}$ ): $140 \mathrm{CsCl}, 0.1$ EGTA, $1 \mathrm{MgCl}_{2}, 10 \mathrm{HEPES}$, $\mathrm{pH} 7.2$ adjusted with CsOH. Currents were measured using 500-ms voltage ramps from $+100 \mathrm{mV}$ to $-100 \mathrm{mV}$ in 2-s intervals with the holding potential of $0 \mathrm{mV}$. Shown are time courses of currents at $+100 \mathrm{mV}$ (open circles) and $-100 \mathrm{mV}$ (filled circles), in response to the application of $10 \mu \mathrm{mol} \mathrm{L}{ }^{-1}$ Oxo-M and $100 \mathrm{nmol} \mathrm{L}{ }^{-1}$ DAMGO to simultaneously activate the muscarinic (endogenously expressed) and $\mu$-opioid (transfected) receptors, respectively. B, Current-voltage relationships recorded from the same cell by the voltage ramp collected before agonist application (basal, blue line) and at the peak of the agonist response (red line).

on TRPC4. TRPC4 was blocked by FFA, MFA, NFA and DFS with $\mathrm{IC}_{50}$ values of $55 \pm 5,84 \pm 8,102 \pm 9$, and $138 \pm 7$ $\mu \mathrm{mol} \mathrm{L} \mathrm{L}^{-1}$, respectively [70]. The potency of inhibition was shown to depend on modifications of the 2-phenylaminobenzoate skeleton and a structure-activity relationship has been described for FFA analogues with modifications of the phenylamino ring [70]. Interestingly, fenamate analogues with differential effects on TRPC4 and TRPC5 channels, showing inhibition with acute but potentiation with long exposure, have also been identified [70]. SKF-96365 and 2-aminoethoxydiphenyl borate (2APB) are non-specific blockers commonly used to inhibit TRPC channels. Receptor-activated TRPC4 was blocked by $50 \mu \mathrm{mol} \mathrm{L}^{-1}$ SKF-96365 [73,74] or by $75 \mu \mathrm{mol} \mathrm{L^{-1 }}$ 2APB [73,75]. However, the lack of specificity is a major concern for the use of these drugs in establishing the contribution of TRPC4-containing channels in native systems.

The steroid hormone progesterone was found to inhibit TRPC4 channel activity with an $\mathrm{IC}_{50}$ of $6.2 \mu \mathrm{mol} \mathrm{L}{ }^{-1}$ [76]. However, this effect appears to be common for most TRPC channels, except TRPC5, suggesting that at the high gestational levels of progesterone, TRPC channels could be inhibited. It was conducive that this effect may be important for minimizing uterine contractility and immunosuppression during pregnancy [76]. Table 1 shows the structures and potency of small molecules that have been shown to inhibit TRPC4 channels.

In whole-cell recordings, receptor-evoked activation of TRPC $4 \alpha$, but not TRPC $4 \beta$, was strongly inhibited by the application of diC8 form of $\mathrm{PI}(4,5) \mathrm{P}_{2}$ through pipette dialysis. In contrast, several other phosphoinositides, including $\mathrm{PI}(3,4) \mathrm{P}_{2}, \mathrm{PI}(3,5) \mathrm{P}_{2}$, and $\mathrm{PI}(3,4,5) \mathrm{P}_{3}$, did not mimic the inhibitory effect of $\mathrm{PI}(4,5) \mathrm{P}_{2}$; some of them even potentiated the activity of TRPC $4 \alpha$ [47]. PI(4,5) $\mathrm{P}_{2}$ bound to the $\mathrm{C}$ terminus of TRPC $4 \alpha$ but not that of TRPC $4 \beta$ in vitro and its inhibitory action was abolished by the treatment with cytochalasin D or by the deletion of the C-terminal PDZ-binding motif, indicative of a dependence on the association of TRPC $4 \alpha$ with actin cytoskeleton [47]. On the other hand, as mentioned above, $\mathrm{PI}(4,5) \mathrm{P}_{2}$ has been suggested to be an essential lipid for sustaining the open state of TRPC $4 \beta$ [48]. Furthermore, intracellular dialysis of a short peptide, EQVTTRL, representing the last seven C-terminal amino acids of TRPC5 with the PDZ-binding motif, inhibited the carbachol-induced plateau potentials in entorhinal cortical neurons, which were thought to be mediated by channels formed by TRPC4 and/or TRPC5 [77].

\section{Outlook and challenges}

TRPC4 isoforms form nonselective cation channels that integrate signaling pathways activated from stimulation of $\mathrm{G}$ protein-coupled receptors and receptor tyrosine kinases. It remains debated about the activation mechanism of TRPC4 channels. A number of early studies supported the view that TRPC4 was essential for store-operated or $\mathrm{Ca}^{2+}$ release-activated $\mathrm{Ca}^{2+}$ (CRAC) channels [27,28,58,59]. However, subsequent studies showed that only neurotransmitter-induced receptor-operated channels were impaired in the TRPC4 knockout mice [37,45]. Because of the recent demonstration of the involvement of STIM and Orai proteins in CRAC channel [62], physical and functional interactions between STIM1/Orail and with TRPC1 or TRPC4 channels to contribute to store-operated $\mathrm{Ca}^{2+}$ entry have been suggested $[60,61]$. Further studies are warranted to examine the interaction between TRPC4 and STIM/Orai and define the role of TRPC4 in store-operated $\mathrm{Ca}^{2+}$ entry.

TRPC4 proteins are abundantly expressed in brain neurons and smooth muscle cells, where they form $\mathrm{Ca}^{2+}$ permeable nonselective cation channels implicated in di- 
Table 1 Summary of TRPC4 channel inhibitors

\begin{tabular}{|c|c|c|c|c|}
\hline Compound name & Structure & Concentration effect on TRPC4 & Selectivity on channels & Refs \\
\hline ML204 & & $\mathrm{IC}_{50}=0.96 \mu \mathrm{mol} \mathrm{L}^{-1}$ & $\begin{array}{l}\text { No effect on TRPV1, TRPV3, TRPA1 } \\
\text { and TRPM8 or native voltage-gated } \mathrm{Na}^{+} \text {, } \\
\qquad \mathrm{K}^{+}, \mathrm{Ca}^{2+} \text { channels }\end{array}$ & {$[66]$} \\
\hline Flufenamic acid (FFA) & & $\mathrm{IC}_{50}=55 \pm 5 \mu \mathrm{mol} \mathrm{L}-1$ & $\begin{array}{l}\text { Effect on } \mathrm{Ca}^{2+}-\text { activated } \mathrm{Cl}^{-} \text {channels, } \\
\text { voltage-gated } \mathrm{Na}^{+}, \mathrm{K}^{+} \text {or } \mathrm{Ca}^{2+} \text { channels, } \\
\text { and other TRP channels }\end{array}$ & [70] \\
\hline Mefenamic acid (MFA) & & $\mathrm{IC}_{50}=84 \pm 8 \mu \mathrm{mol} \mathrm{L}^{-1}$ & $\begin{array}{l}\text { Effect on } \mathrm{Ca}^{2+} \text { - activated } \mathrm{Cl}^{-} \text {channels, } \\
\text { voltage-gated } \mathrm{Na}^{+}, \mathrm{K}^{+} \text {or } \mathrm{Ca}^{2+} \text { channels, } \\
\text { and other TRP channels }\end{array}$ & {$[70]$} \\
\hline Niflumic acid (NFA) & & $\mathrm{IC}_{50}=102 \pm 9 \mu \mathrm{mol} \mathrm{L}^{-1}$ & $\begin{array}{l}\text { Effect on } \mathrm{Ca}^{2+} \text { - activated } \mathrm{Cl}^{-} \text {channels, } \\
\text { voltage-gated } \mathrm{Na}^{+}, \mathrm{K}^{+} \text {or } \mathrm{Ca}^{2+} \text { channels, } \\
\text { and other TRP channels }\end{array}$ & {$[70]$} \\
\hline Progesterone & & $\mathrm{IC}_{50}=6.2 \mu \mathrm{mol} \mathrm{L}-1$ & $\begin{array}{c}\text { Effect on TRPC3, TRPC5, TRPC6 } \\
\text { channels }\end{array}$ & [76] \\
\hline $\begin{array}{l}\text { 2-aminoethoxydiphenyl } \\
\text { borate ( } 2 \mathrm{APB})\end{array}$ & & Blocked at $75 \mu \mathrm{mol} \mathrm{L}{ }^{-1}$ & $\begin{array}{l}\text { Inhibits } \mathrm{IP}_{3} \mathrm{Rs}, \mathrm{TRPC} \text { and TRPM chan- } \\
\text { nels, activates TRPA1 and some TRPV } \\
\text { channels }\end{array}$ & {$[73,75]$} \\
\hline SKF-96365 & & Blocked at $50 \mu \mathrm{mol} \mathrm{L}{ }^{-1}$ & $\begin{array}{l}\text { Nonselective for TRPC channels, } \\
\text { store-operated } \mathrm{Ca}^{2+} \text { entry, and volt- } \\
\text { age-gated } \mathrm{Ca}^{2+} \text { channels }\end{array}$ & {$[73,74]$} \\
\hline $\begin{array}{c}\text { DIDS } \\
\text { (4,4'-dixothiocyanatositben } \\
\text { e-2,2'-disulfonic acid) }\end{array}$ & & Blocked at $10 \mu \mathrm{mol} \mathrm{L}^{-1}$ & $\begin{array}{l}\text { Inhibits } \mathrm{Cl}^{-} \text {uptake, activates volt- } \\
\text { age-gated } \mathrm{K}^{+} \text {channels }\end{array}$ & {$[36]$} \\
\hline
\end{tabular}

verse physiological functions, including smooth muscle contractility and synaptic transmission [30,34,37,45]. In addition, genetic analyses have found association of TRPC4 variants with human disease $[41,42]$. It is thus foreseeable that TRPC4 channels have important physiological significance and are valuable therapeutic drug targets. However, functional characterization of TRPC4 channels in native tissues has been hampered by the lack of specific pharmacological tools. Efforts have been undertaken to screen for small molecular modulators using a cell-based fluorescence assay. Uniquely, co-expression of TRPC $4 \beta$ with the $\mu$ opioid receptor in HEK293 cells resulted in an intracellular $\mathrm{Ca}^{2+}$ response to stimulation by the $\mu$ agonist, DAMGO, which was lacking with the expression of either TRPC4 or the opioid receptor alone [66]. The very low background of this system allowed for fluorescence-based high throughput screening using cells loaded with the calcium specific fluorescent indicator, such as fluo-4. The DAMGO-induced intracellular $\mathrm{Ca}^{2+}$ concentration rise was almost entirely dependent on TRPC4 $\beta$-mediated $\mathrm{Ca}^{2+}$ entry. This approach had led to identification of multiple lead compounds, which were further tested to remove those that targeted the $\mu$ opioid receptor and $\mathrm{G}$ proteins. Promising lead compounds have been confirmed using patch-clamp recordings, the gold standard for ion channel drug screening [66]. It is anticipated that more new small molecular probes for TRPC4 will be 
uncovered in the near future and some of them will possess the desired high potency and selectivity and be suitable for development of drug therapies targeting at TRPC4.

This work was supported in part by the National Natural Science Foundation of China (81228021) and US National Institutes of Health (DK081654).

1 Montell C. The TRP superfamily of cation channels. Sci STKE, 2005, 2005: re3

2 Venkatachalam K, Montell C. TRP channels. Annu Rev Biochem, 2007, 76: 387-417

3 Zitt C, Halaszovich CR, Luckhoff A. The TRP family of cation channels: probing and advancing the concepts on receptor-activated calcium entry. Prog Neurobiol, 2002, 66: 243-264

4 Vazquez G, Wedel BJ, Aziz O, Trebak M, Putney JW Jr. The mammalian TRPC cation channels. Biochim Biophys Acta, 2004, 1742: $21-36$

5 Eder P, Schindl R, Romanin C, Groschner K. Protein-protein interactions in TRPC channel complexes. In: Liedtke WB, Heller S, eds. TRP Ion Channel Function in Sensory Transduction and Cellular Signaling Cascades. Boca Raton (FL): CRC Press, 2007. Chapter 24

6 Poteser M, Graziani A, Rosker C, Eder P, Derler I, Kahr H, Zhu MX, Romanin C, Groschner K. TRPC3 and TRPC4 associate to form a redox-sensitive cation channel. Evidence for expression of native TRPC3-TRPC4 heteromeric channels in endothelial cells. J Biol Chem, 2006, 281: 13588-13595

7 Ma X, Cheng KT, Wong CO, O’Neil RG, Birnbaumer L, Ambudkar IS, Yao X. Heteromeric TRPV4-C1 channels contribute to store-operated $\mathrm{Ca}^{2+}$ entry in vascular endothelial cells. Cell Calcium, 2011, 50: 502-509

8 Kobori T, Smith GD, Sandford R, Edwardson JM. The transient receptor potential channels TRPP2 and TRPC1 form a heterotetramer with a 2:2 stoichiometry and an alternating subunit arrangement. J Biol Chem, 2009, 284: 35507-35513

9 Liu X, Bandyopadhyay BC, Singh BB, Groschner K, Ambudkar IS. Molecular analysis of a store-operated and 2-acetyl-sn-glycerolsensitive non-selective cation channel. Heteromeric assembly of TRPC1-TRPC3. J Biol Chem, 2005, 280: 21600-21606

10 Schindl R, Fritsch R, Jardin I, Frischauf I, Kahr H, Muik M, Riedl MC, Groschner K, Romanin C. Canonical transient receptor potential (TRPC) 1 acts as a negative regulator for vanilloid TRPV6-mediated $\mathrm{Ca}^{2+}$ influx. J Biol Chem, 2012, 287: 35612-35620

11 Philipp S, Cavalie A, Freichel M, Wissenbach U, Zimmer S, Trost C, Marquart A, Murakami M, Flockerzi V. A mammalian capacitative calcium entry channel homologous to Drosophila TRP and TRPL. EMBO J, 1996, 15: 6166-6171

12 McKay RR, Szymeczek-Seay CL, Lievremont JP, Bird GS, Zitt C, Jungling E, Luckhoff A, Putney JW Jr. Cloning and expression of the human transient receptor potential 4 (TRP4) gene: localization and functional expression of human TRP4 and TRP3. Biochem J, 2000, 351: 735-746

13 Schaefer M, Plant TD, Obukhov AG, Hofmann T, Gudermann T, Schultz G. Receptor-mediated regulation of the nonselective cation channels TRPC4 and TRPC5. J Biol Chem, 2000, 275: 17517-17526

14 Schaefer M, Plant TD, Stresow N, Albrecht N, Schultz G. Functional differences between TRPC4 splice variants. J Biol Chem, 2002, 277: 3752-3759

15 Tang J, Lin Y, Zhang Z, Tikunova S, Birnbaumer L, Zhu MX. Identification of common binding sites for calmodulin and inositol 1,4,5-trisphosphate receptors on the carboxyl termini of trp channels. J Biol Chem, 2001, 276: 21303-21310

16 Trost C, Bergs C, Himmerkus N, Flockerzi V. The transient receptor potential, TRP4, cation channel is a novel member of the family of calmodulin binding proteins. Biochem J, 2001, 355: 663-670

17 Yuan JP, Kiselyov K, Shin DM, Chen J, Shcheynikov N, Kang SH,
Dehoff MH, Schwarz MK, Seeburg PH, Muallem S, Worley PF. Homer binds TRPC family channels and is required for gating of TRPC1 by IP3 receptors. Cell, 2003, 114: 777-789

18 Greka A, Navarro B, Oancea E, Duggan A, Clapham DE. TRPC5 is a regulator of hippocampal neurite length and growth cone morphology. Nat Neurosci, 2003, 6: 837-845

19 Garcia RL, Schilling WP. Differential expression of mammalian TRP homologues across tissues and cell lines. Biochem Biophys Res Commun, 1997, 239: 279-283

20 Mery L, Magnino F, Schmidt K, Krause KH, Dufour JF. Alternative splice variants of hTrp4 differentially interact with the C-terminal portion of the inositol 1,4,5-trisphosphate receptors. FEBS Lett, 2001, 487: 377-383

21 Miehe S, Bieberstein A, Arnould I, Ihdene O, Rutten H, Strubing C. The phospholipid-binding protein SESTD1 is a novel regulator of the transient receptor potential channels TRPC4 and TRPC5. J Biol Chem, 2010, 285: 12426-12434

22 Jeon JP, Hong C, Park EJ, Jeon JH, Cho NH, Kim IG, Choe H, Muallem S, Kim HJ, So I. Selective Galphai subunits as novel direct activators of transient receptor potential canonical (TRPC) 4 and TRPC5 channels. J Biol Chem, 2012, 287: 17029-17039

23 Odell AF, Van Helden DF, Scott JL. The spectrin cytoskeleton influences the surface expression and activation of human transient receptor potential channel 4 channels. J Biol Chem, 2008, 283: 4395-4407

24 Fanning AS, Anderson JM. Protein-protein interactions: PDZ domain networks. Curr Biol, 1996, 6: 1385-1388

25 Tang Y, Tang J, Chen Z, Trost C, Flockerzi V, Li M, Ramesh V, Zhu MX. Association of mammalian trp4 and phospholipase $\mathrm{C}$ isozymes with a PDZ domain-containing protein, NHERF. J Biol Chem, 2000, 275: 37559-37564

26 Mery L, Strauss B, Dufour JF, Krause KH, Hoth M. The PDZ-interacting domain of TRPC4 controls its localization and surface expression in HEK293 cells. J Cell Sci, 2002, 115: 3497-3508

27 Freichel M, Suh SH, Pfeifer A, Schweig U, Trost C, Weissgerber P, Biel M, Philipp S, Freise D, Droogmans G, Hofmann F, Flockerzi V, Nilius B. Lack of an endothelial store-operated $\mathrm{Ca}^{2+}$ current impairs agonist-dependent vasorelaxation in $\mathrm{TRP}^{-/-}$mice. Nat Cell Biol, 2001, 3: 121-127

28 Tiruppathi C, Freichel M, Vogel SM, Paria BC, Mehta D, Flockerzi $\mathrm{V}$, Malik AB. Impairment of store-operated $\mathrm{Ca}^{2+}$ entry in $\mathrm{TRPC}^{-/-}$ mice interferes with increase in lung microvascular permeability. Circ Res, 2002, 91: 70-76

29 Obukhov AG, Nowycky MC. TRPC4 can be activated by G-protein-coupled receptors and provides sufficient $\mathrm{Ca}^{2+}$ to trigger exocytosis in neuroendocrine cells. J Biol Chem, 2002, 277: $16172-16178$

30 Munsch T, Freichel M, Flockerzi V, Pape HC. Contribution of transient receptor potential channels to the control of GABA release from dendrites. Proc Natl Acad Sci USA, 2003, 100: 16065-16070

31 El-Hassar L, Hagenston AM, D'Angelo LB, Yeckel MF. Metabotropic glutamate receptors regulate hippocampal CA1 pyramidal neuron excitability via $\mathrm{Ca}^{2+}$ wave-dependent activation of SK and TRPC channels. J Physiol, 2011, 589: 3211-3229

32 Phelan KD, Mock MM, Kretz O, Shwe UT, Kozhemyakin M, Greenfield LJ, Dietrich A, Birnbaumer L, Freichel M, Flockerzi V, Zheng F. Heteromeric canonical transient receptor potential 1 and 4 channels play a critical role in epileptiform burst firing and seizure-induced neurodegeneration. Mol Pharmacol, 2012, 81: 384-392

33 Phelan K, Shwe U, Abramowitz J, Wu H, Rhee S, Howell M, Gottschall P, Freichel M, Flockerzi V, Birnbaumer L, Zheng F. Canonical transient receptor channel 5 (TRPC5) and TRPC1/4 contribute to seizure and excitotoxicity by distinct cellular mechanisms. Mol. Pharmacol, 2013, 83: 429-438

34 Stroh O, Freichel M, Kretz O, Birnbaumer L, Hartmann J, Egger V. NMDA receptor-dependent synaptic activation of TRPC channels in 
olfactory bulb granule cells. J Neurosci, 2012, 32: 5737-5746

35 Torihashi S, Fujimoto T, Trost C, Nakayama S. Calcium oscillation linked to pacemaking of interstitial cells of Cajal: requirement of calcium influx and localization of TRP4 in caveolae. J Biol Chem, 2002, 277: 19191-19197

36 Walker RL, Koh SD, Sergeant GP, Sanders KM, Horowitz B. TRPC4 currents have properties similar to the pacemaker current in interstitial cells of Cajal. Am J Physiol Cell Physiol, 2002, 283: C1637-1645

37 Tsvilovskyy VV, Zholos AV, Aberle T, Philipp SE, Dietrich A, Zhu MX, Birnbaumer L, Freichel M, Flockerzi V. Deletion of TRPC4 and TRPC6 in mice impairs smooth muscle contraction and intestinal motility in vivo. Gastroenterology, 2009, 137: 1415-1424

38 Antigny F, Koenig S, Bernheim L, Frieden M. During post-natal human myogenesis, normal myotube size requires TRPC1- and TRPC4-mediated $\mathrm{Ca}^{2+}$ entry. J Cell Sci, 2013, 126: 2525-2533

39 Beck B, Lehen'kyi V, Roudbaraki M, Flourakis M, Charveron M, Bordat P, Polakowska R, Prevarskaya N, Skryma R. TRPC channels determine human keratinocyte differentiation: new insight into basal cell carcinoma. Cell Calcium, 2008, 43: 492-505

40 Weick JP, Austin Johnson M, Zhang SC. Developmental regulation of human embryonic stem cell-derived neurons by calcium entry via transient receptor potential channels. Stem Cells, 2009, 27: 2906-2916

41 von Spiczak S, Muhle H, Helbig I, de Kovel CG, Hampe J, Gaus V, Koeleman BP, Lindhout D, Schreiber S, Sander T, Stephani U. Association study of TRPC4 as a candidate gene for generalized epilepsy with photosensitivity. Neuromol Med, 2010, 12: 292-299

42 Jung C, Gené GG, Tomás M, Plata C, Selent J, Pastor M, Fandos C, Senti M, Lucas G, Elosua R, Valverde MA. A gain-of-function SNP in TRPC4 cation channel protects against myocardial infarction. Cardiovasc Res, 2011, 91: 465-471

43 Qiu J, Fang Y, Ronnekleiv OK, Kelly MJ. Leptin excites proopiomelanocortin neurons via activation of TRPC channels. J Neurosci, 2010, 30: 1560-1565

44 Riccio A, Li Y, Moon J, Kim KS, Smith KS, Rudolph U, Gapon S, Yao GL, Tsvetkov E, Rodig SJ, Van't Veer A, Meloni EG, Carlezon WA Jr, Bolshakov VY, Clapham DE. Essential role for TRPC5 in amygdala function and fear-related behavior. Cell, 2009, 137: 761-772

45 Riccio A, Li Y, Tsvetkov E, Gapon S, Yao GL, Smith KS, Engin E, Rudolph U, Bolshakov VY, Clapham DE. Decreased anxiety-like behavior and $\mathrm{G} \alpha_{\mathrm{q} / 11}$-dependent responses in the amygdala of mice lacking TRPC4 channels. J Neurosci, 2014, 34: 3653-3667

46 Plant TD, Schaefer M. TRPC4 and TRPC5: receptor-operated $\mathrm{Ca}^{2+}$-permeable nonselective cation channels. Cell Calcium, 2003, 33: $441-450$

47 Otsuguro K, Tang J, Tang Y, Xiao R, Freichel M, Tsvilovskyy V, Ito S, Flockerzi V, Zhu MX, Zholos AV. Isoform-specific inhibition of TRPC4 channel by phosphatidylinositol 4,5-bisphosphate. J Biol Chem, 2008, 283: 10026-10036

48 Kim H, Jeon JP, Hong C, Kim J, Myeong J, Jeon JH, So I. An essential role of $\mathrm{PI}(4,5) \mathrm{P}_{2}$ for maintaining the activity of the transient receptor potential canonical (TRPC) $4 \beta$. Pflugers Arch, 2013, 465: 1011-1021

49 Runnels LW, Yue L, Clapham DE. The TRPM7 channel is inactivated by $\mathrm{PIP}_{2}$ hydrolysis. Nat Cell Biol, 2002, 4: 329-336

50 Liu B, Qin F. Functional control of cold- and menthol-sensitive TRPM8 ion channels by phosphatidylinositol 4,5-bisphosphate. J Neurosci, 2002, 25: 1674-1681

51 Rohács T, Lopes CM, Michailidis I, Logothetis DE. PI(4,5) $\mathrm{P}_{2}$ regulates the activation and desensitization of TRPM8 channels through the TRP domain. Nat Neurosci, 2005, 8: 626-634

52 Zhang Z, Okawa H, Wang Y, Liman ER. Phosphatidylinositol 4,5-bisphosphate rescues TRPM4 channels from desensitization. J Biol Chem, 2005, 280: 39185-39192

53 Imai Y, Itsuki K, Okamura Y, Inoue R, Mori MX. A self-limiting regulation of vasoconstrictor-activated TRPC3/C6/C7 channels cou- pled to $\mathrm{PI}(4,5) \mathrm{P}_{2}$-diacylglycerol signalling. J Physiol, 2012, 590: 1101-1119

54 Zholos AV, Bolton TB. Muscarinic receptor subtypes controlling the cationic current in guinea-pig ileal smooth muscle. Br J Pharmacol, 1997, 122: 885-893

55 Pucovský V, Zholos AV, Bolton TB. Muscarinic cation current and suppression of $\mathrm{Ca}^{2+}$ current in guinea pig ileal smooth muscle cells. Eur J Pharmacol, 1998, 346: 323-330

56 Xu SZ, Zeng B, Daskoulidou N, Chen GL, Atkin SL, Lukhele B. Activation of TRPC cationic channels by mercurial compounds confers the cytotoxicity of mercury exposure. Toxicol Sci, 2012, 125: 56-68

57 Yoshida T, Inoue R, Morii T, Takahashi N, Yamamoto S, Hara Y, Tominaga M, Shimizu S, Sato Y, Mori Y. Nitric oxide activates TRP channels by cysteine S-nitrosylation. Nat Chem Biol, 2006, 2: 596-607

58 Philipp S, Trost C, Warnat J, Rautmann J, Himmerkus N, Schroth G, Kretz O, Nastainczyk W, Cavalie A, Hoth M, Flockerzi V. TRP4 (CCE1) protein is part of native calcium release-activated $\mathrm{Ca}^{2+}$-like channels in adrenal cells. J Biol Chem, 2000, 275: 23965-23972

59 Wang X, Pluznick JL, Wei P, Padanilam BJ, Sansom SC. TRPC4 forms store-operated $\mathrm{Ca}^{2+}$ channels in mouse mesangial cells. Am J Physiol Cell Physiol, 2004, 287: C357-364

60 Yuan JP, Kim MS, Zeng W, Shin DM, Huang G, Worley PF, Muallem S. TRPC channels as STIM1-regulated SOCs. Channels (Austin), 2009, 3: 221-225

61 Sours-Brothers S, Ding M, Graham S, Ma R. Interaction between TRPC1/TRPC4 assembly and STIM1 contributes to store-operated $\mathrm{Ca}^{2+}$ entry in mesangial cells. Exp Biol Med (Maywood), 2009, 234: 673-682

62 Cahalan MD, Zhang SL, Yeromin AV, Ohlsen K, Roos J, Stauderman KA. Molecular basis of the CRAC channel. Cell Calcium, 2007, 42: 133-144

63 Semtner M, Schaefer M, Pinkenburg O, Plant TD. Potentiation of TRPC5 by protons. J Biol Chem, 2007, 282: 33868-33878

64 Jung S, Muhle A, Schaefer M, Strotmann R, Schultz G, Plant TD. Lanthanides potentiate TRPC5 currents by an action at extracellular sites close to the pore mouth. J Biol Chem, 2003, 278: 3562-3571

65 Zhang L, Kolaj M, Renaud LP. GIRK-like and TRPC-like conductances mediate thyrotropin-releasing hormone-induced increases in excitability in thalamic paraventricular nucleus neurons. Neuropharmacology, 2013, 72: 106-115

66 Miller M, Shi J, Zhu Y, Kustov M, Tian JB, Stevens A, Wu M, Xu J, Long S, Yang P, Zholos AV, Salovich JM, Weaver CD, Hopkins CR, Lindsley CW, McManus O, Li M, Zhu MX. Identification of ML204, a novel potent antagonist that selectively modulates native TRPC4/C5 ion channels. J Biol Chem, 2011, 286: 33436-33446

67 Westlund KN, Zhang LP, Ma F, Nesemeier R, Ruiz JC, Ostertag EM, Crawford JS, Babinski K, Marcinkiewicz MM. A rat knockout model implicates TRPC4 in visceral pain sensation. Neuroscience, 2014, 262C: 165-175

68 Schaldecker T, Kim S, Tarabanis C, Tian D, Hakroush S, Castonguay P, Ahn W, Wallentin H, Heid H, Hopkins CR, Lindsley CW, Riccio A, Buvall L, Weins A, Greka A. Inhibition of the TRPC5 ion channel protects the kidney filter. J Clin Invest, 2013, 123: 5298-5309

69 Zhang L, Kolaj M and Renaud LP. GIRK-like and TRPC-like conductances mediate thyrotropin-releasing hormone-induced increases in excitability in thalamic paraventricular nucleus neurons. Neuropharmacology, 2013, 72: 106-115

70 Jiang H, Zeng B, Chen GL, Bot D, Eastmond S, Elsenussi SE, Atkin SL, Boa AN, Xu SZ. Effect of non-steroidal anti-inflammatory drugs and new fenamate analogues on TRPC4 and TRPC5 channels. Biochem Pharmacol, 2012, 83: 923-931

71 Xiong Q, Gao Z, Wang W, Li M. Activation of Kv7 (KCNQ) voltage-gated potassium channels by synthetic compounds. Trends Pharmacol Sci, 2008, 29: 99-107

72 Hu H, Tian J, Zhu Y, Wang C, Xiao R, Herz JM, Wood JD, Zhu MX. Activation of TRPA1 channels by fenamate nonsteroidal antiinflammatory drugs. Pflugers Arch, 2009, 459: 579-592 
73 Wimmers S, Strauss O. Basal calcium entry in retinal pigment epithelial cells is mediated by TRPC channels. Invest Ophthalmol Vis Sci, 2007, 48: 5767-5772

74 Singh A, Hildebrand ME, Garcia E, Snutch TP. The transient receptor potential channel antagonist SKF96365 is a potent blocker of low-voltage-activated T-type calcium channels. Br J Pharmacol, 2010, 160: 1464-1475

75 Xu SZ, Zeng F, Boulay G, Grimm C, Harteneck C, Beech DJ. Block of TRPC5 channels by 2-aminoethoxydiphenyl borate: a differential, extracellular and voltage-dependent effect. Br J Pharmacol, 2005, 145: 405-414

76 Miehe S, Crause P, Schmidt T, Lohn M, Kleemann HW, Licher T, Dittrich W, Rutten H, Strubing C. Inhibition of diacylglycerolsensitive TRPC channels by synthetic and natural steroids. PLoS One, 2012, 7:e35393

77 Zhang Z, Reboreda A, Alonso A, Barker P, Séguéla P. TRPC channels underlie cholinergic plateau potentials and persistent activity in entorhinal cortex. Hippocampus, 2011, 21: 386-397

Open Access This article is distributed under the terms of the Creative Commons Attribution License which permits any use, distribution, and reproduction in any medium, provided the original author(s) and source are credited. 